\title{
LETRAMENTO CÍVICO NA EJA: OTRABALHO COM OS GÊNEROS DISCURSIVOS EM PROJETOS DE LETRAMENTO
}

\author{
LA LITERACIA CÍVICA EN LA EDUCACIÓN DE JÓVENES Y ADULTOS: EL TRABAJO CON GÉNEROS \\ DISCURSIVOS EM PROYECTOS DE LITERACIA
}

\author{
CIVIC LITERACY IN YOUTH AND ADULT EDUCATION: WORKING WITH DISCOURSE GENRES \\ THROUGH LITERACY PROJECTS
}

\author{
Ivoneide Bezerra de Araújo Santos* \\ Instituto Federal de Educação, Ciência e Tecnologia do Rio Grande do Norte - IFRN, Natal, BR
}

\begin{abstract}
RESUMO: O objetivo deste trabalho é refletir sobre o caráter agentivo da escrita e o papel dos gêneros discursivos na formação de agentes de letramento, visando à ação e à mudança social. A nossa discussão está ancorada na concepção de linguagem de base bakhtiniana (BAKHTIN, 2003); nos estudos de letramento (KLEIMAN, 1995; BAYNHAM, 1995; BARTON; HAMILTON; IVANIC, 2000, LAZERE, 2005); nos estudos críticos defensores da ideia de que todos os textos se constituem em instrumentos ideológicos capazes de conferir poder aos indivíduos (MCLAREN, 1997; FREIRE, 1979, 1996, 2001; GIROUX, 1997); na abordagem social de gênero inspirada na Nova Retórica (BAZERMAN, 2006; 2007). Trata-se de uma pesquisa de natureza etnográfica cujos dados em análise foram gerados a partir de projetos de letramento (KLEIMAN, 2000) desenvolvidos com alunos da Educação de Jovens e Adultos, no ano letivo de 2006, em uma escola da rede pública de Natal-RN. O estudo permitiu-nos depreender, em primeiro lugar, que o trabalho com os gêneros discursivos abre a possibilidade para que o estudante leia e escreva para agir discursivamente no mundo social, ganhando, assim, empoderamento; em segundo lugar, que envolver alunos em projetos de letramento vai além de uma competência didática vinculada a especificidades e ao domínio de conteúdos, sendo preciso que o professor saiba para quem, o que, por que e como ensinar e que assuma uma postura reflexiva, tornando-se também um aprendiz; em terceiro lugar, que a partir das práticas de letramento desenvolvidas, os alunos construíram uma visão mais consciente e crítica em relação à língua e ao mundo social no qual atuaram como cidadãos interventivos e politizados.

PALAVRAS-CHAVE: gêneros discursivos; letramento cívico; empoderamento; emancipação; EJA.
\end{abstract}

RESUMEN: El objetivo de este trabajo es reflexionar sobre el carácter personal de la escrita y el papel de los géneros discursivos en la formación de formadores de la literacia, con el objetivo de llevar a la acción y al cambio social. Nuestra discusión se ampara en la concepción de lenguaje de base bakhtiniana (BAKHTIN, 2003); en los estudios de la literacia (KLEIMAN, 1995; BAYNHAM, 1995; BARTON; HAMILTON; IVANIC, 2000, LAZERE, 2005); en los estudios críticos que defienden la idea de que todos los textos se constituyen como instrumentos ideológicos capaces de conferir poder a los individuos (MCLAREN, 1997; FREIRE, 1979, 1996, 2001; GIROUX, 1997); en el abordaje social de género inspirado en la Nueva Retórica (BAZERMAN, 2006; 2007). Se trata de una investigación de naturaleza etnográfica cuyos datos en análisis fueron generados a partir de proyectos de literacia (KLEIMAN, 2000) desarrollados con estudiantes de la Educación de Jóvenes y Adultos, en el año lectivo de 2006, en una escuela de la red pública de Natal-RN. El estudio nos permitió entender, en primer lugar, que el trabajo com géneros discursivos abre la posibilidad de que el estudiante lea y escriba para actuar discursivamente en el mundo social, ganando, de ese modo, empoderamento; en segundo lugar, quiere involucrar alumnos en proyectos de literacia que sobrepasen un nivel de competencia didáctica vinculada a especificidades y al dominio de contenidos, siendo necesario que el profesor sepa a quien, qué, por qué y cómo enseñar y que asuma una postura reflexiva, poniéndose, también él, en la posición de aprendiz; en tercero lugar, que a partir de las prácticas de literacia desarrolladas, los alumnos construyan una visión más consciente y crítica con respecto a la lengua y al mundo social en el que actúan como ciudadanos que cuentan y que tienen participación política.

PALABRAS-CLAVE: géneros discursivos; literacia cívica; empoderamento; emancipación; EJA.

ABSTRACT: This study aims to reflect on the agentive character of writing and the role of discursive genres on the education of literacy agents seeking action and social change. Our discussion is based on Bakhtin's conception of language (BAKHTIN, 2003); on literacy studies (KLEIMAN, 1995; BAYNHAM, 1995; BARTON; HAMILTON; IVANIC, 2000, LAZERE, 2005); on critical studies which support the idea that all texts are ideological tools that can empower individuals (MCLAREN, 1997; FREIRE, 1979, 1996, 2001; GIROUX, 1997) and on social genre approach inspired on New Rhetoric (BAZERMAN, 2006; 2007). Data was generated from literacy projects through an ethnographic perspective (KLEIMAN, 2000). The literacy projects were developed with Young Adults and Middle-Aged Education (EJA) students during the school year of 2006 in a regular and governmental school in Natal-RN. Based on results, we can firstly say that the work with discursive genre allows that students read and write in order to act discursively on social world, empowering themselves; Secondly, it can be said that the students participation in literacy projects goes beyond a didactic competence related to specificities and to the domain of content, what means that the teacher needs to know what, to whom, why and how to teach. Thus the teacher needs to assume a reflexive posture, acting as a learner. Thirdly, it's possible to affirm that based on the literacy practices which were developed in the Project, students built a more conscious and critic vision regarding language and the social world in which they acted as politic citizens who may intervene in the world they live in.

KEYWORDS: discursive genre; civic literacy; empowerment; emancipation; EJA.

*Email: ivoneidebezerra@gmail.com. 
Eu queria uma escola que lhes ensinasse a usar bem a nossa língua, a pensar e a se expressar com clareza.

Eu queria uma escola que lhes ensinasse a pensar, a raciocinar, a procurar soluções.

(Carlos Drummond de Andrade)

\section{INTRODUÇÃO}

Embora tenha sido idealizada pela retórica e pela crítica literária para identificar os gêneros clássicos (lírico, épico e dramático), além de outros mais modernos também pertencentes à esfera literária, como o romance, o conto, a novela etc., a palavra gênero parece ter sido incorporada, atualmente, ao repertório dos professores de língua materna. No Brasil, ela está em evidência há mais de uma década, desde a publicação dos Parâmetros Curriculares Nacionais (PCN) (BRASIL, 1998), sendo um tema frequentemente discutido no debate didático de como ensinar a língua materna na escola.

Essa discussão sobre gênero e ensino justifica-se não apenas por ser aquele o instrumento para a efetivação da comunicação verbal, mas, fundamentalmente, porque os documentos oficiais reguladores do ensino da língua passam a considerá-lo, a partir de então, como atividade de interação social, respaldada numa concepção dialógica da linguagem. Nessa perspectiva, em tese, o ensino seria mais produtivo e capaz de ampliar a competência comunicativa dos alunos, à medida que buscasse a vinculação das práticas escolares às práticas sociais, tornando aquelas significativas para esses sujeitos. O fato é que a despeito de os professores reconhecerem, em geral, ser importante o trabalho com os gêneros para o desenvolvimento da competência leitora e escritora, nem sempre conseguem, na prática, fazer a mobilização de saberes necessários à formação de leitores e de produtores de textos orais ou escritos na escola e acabam trabalhando sobre os gêneros.

A esse respeito, os resultados de pesquisa evidenciam o fosso existente entre o que está prescrito nos PCN e aquilo que se realiza na escola, considerando que constamos ainda da lista dos países que apresentam déficits na área de leitura e de escrita. Podemos perceber, assim, que não basta dizer o que fazer. É preciso saber fazer. Antes de tudo, é preciso ensinar a fazer. Significa dizer que essa problemática precisa ser considerada também pelas agências formadoras de professores, oferecendo a estes uma formação que lhes dê condições de proporcionar aos alunos um ensino mais produtivo da língua.

No intuito de contribuir com a discussão acerca do trabalho com os gêneros discursivos na escola, o objetivo deste trabalho é refletir sobre a agência de alunos da Educação de Jovens e Adultos (EJA) em eventos de letramento que lhes oportunizaram vivenciar práticas de escrita voltadas para a ação e mudança social. Teceremos algumas considerações sobre o papel que esses sujeitos assumem na comunidade de aprendizagem, o qual os coloca na condição de agentes de letramento (KLEIMAN, 2006).

Os dados foram gerados em 2006, numa escola pública de Natal-RN, e se configuram em diferentes gêneros discursivos, produzidos a partir de um projeto de letramento (KLEIMAN, 2000), em que foram realizadas ações pedagógicas que favoreceram a agência dos estudantes para além da esfera escolar. Na perspectiva em que foi desenvolvido, o trabalho com projetos de letramento teve por fim transformar consciências, visando a emancipação dos educandos mediante o acesso a práticas de linguagem que viabilizem a a luta contra as desigualdades sociais (OLIVEIRA; TINOCO; SANTOS, 2011).

Nossa discussão está ancorada na concepção de linguagem de base bakhtiniana, que tem como princípio fundador o dialogismo (BAKHTIN, 2003); nos estudos de letramento entendido como uma prática social (KLEIMAN, 1995; BAYNHAM, 1995), relevantes por abrirem novas perspectivas para uma reflexão crítica sobre as práticas letradas propostas pela escola; nas reflexões feitas por Barton, Hamilton, Ivanic (2000) a 
respeito das práticas de letramento situadas, por julgarmos que a imersão dos sujeitos em práticas situadas pode levá-los aos discursos institucionais mais amplos, como o da política, por exemplo, interferindo nas ações e atitudes desses sujeitos; na abordagem social de gênero inspirada na Nova Retórica, por considerar o caráter dinâmico, interativo e agentivo dos usos da linguagem (BAZERMAN, 2006; 2007; MILLER, 2009); e nos estudos críticos que defendem a necessidade de se encaminhar o processo de escolarização na perspectiva da pedagogia crítica, no âmbito da qual os textos podem conferir poder aos indivíduos, quando estes, imersos em um processo de letramento cívico, aprendem a ler e a escrever para a participação e a mudança social (LAZERE, 2005; FREIRE, 1971; 1979; 1996; 2001; FREIRE; MACEDO, 1990; MCLAREN, 1997; GIROUX, 1983, 1997).

\section{LETRAMENTO CÍVICO, EMPODERAMENTO E EMANCIPAÇÃO NA EJA}

Neste trabalho, compreende-se o letramento cívico como um modelo crítico e político que oferece aos estudantes as ferramentas para que possam refletir criticamente sobre os fatos e fenômenos e, assim, agir, visando a mudanças no mundo social. A partir dessa compreensão, vislumbra-se contribuir com a emancipação social e cultural dos educandos, oportunizando-lhes o acesso a essa modalidade de letramento cívico, que se vincula a um projeto educacional amplo, alicerçado em princípios políticos, éticos e solidários, promotores da justiça social e da cidadania plena.

Nesse plano de educação para a liberdade, alunos e professores, engajados na investigação da realidade social, preparam-se para assumir posições subjetivas e agir, a fim de engendrar novos meios de vida e de liberdade humanas para aqueles que dele participam, assumindo-o como "um projeto de possibilidade" que permite aos participantes a compreensão e a transformação de sua sociedade (FREIRE; MACEDO, 1990).

Um projeto comprometido com o letramento emancipatório deve viabilizar meios para que os educandos "reconheçam e compreendam suas próprias vozes em meio a uma multidão de discursos com os quais têm que lidar” (FREIRE; MACEDO, 1990, p. 36). Nesse sentido, a escola precisa oferecer as condições necessárias para que, através das práticas letradas desenvolvidas no seu interior, os educandos tanto possam refletir sobre os seus próprios discursos quanto ir além destes. Dessa forma, as vozes sufocadas pelos discursos dominantes encontrariam eco e contribuiriam decisivamente para a legitimação de diferentes vozes, de diferentes discursos.

É importante ressaltar que, embora o conceito de voz seja importante neste trabalho, compreende-se que não basta dar vez e voz aos alunos. É também papel da escola respeitar diferenças dialetais, combatendo o preconceito linguístico, mas é igualmente importante garantir a eles o acesso aos diferentes tipos de registro, particularmente, às variedades cultas, para que possam se inserir no mundo da cultura letrada e do saber escolarizado, podendo ir além da sua própria variante linguística, e compreender que existem diferentes maneiras de dizer sua palavra sem desvalorizar sua forma de dizer, mas reconhecendo que o uso que se faz da língua pode variar dependendo do contexto e da situação em que ela é usada.

É preciso, portanto, que os educandos percebam que sua voz torna-se o meio discursivo para se fazerem ouvir e para intervirem, visando à participação e à mudança social. Contudo, eles precisam também ter acesso à variante padrão como um direito, que tantas vezes a escola lhes tem negado, oferecendo-lhes uma educação linguística "pobre", isto é, limitada, planejada "especialmente" para os que pertencem às classes sociais menos favorecidas, quando minimiza o currículo, "desconsiderando" que o domínio da variedade padrão pode contribuir para torná-los mais empoderados e, assim, aptos a participarem do diálogo com a sociedade.

Aqui, entende-se o empoderamento como decorrência da ação coletiva, medrada por indivíduos que desenvolvem uma maior consciência política e cívica dos direitos sociais, adquirindo uma maior 
compreensão da complexidade das relações sociais que sustentam os contextos econômicos e políticos mais amplos. Na perspectiva de letramento adotada neste trabalho, o conceito de empoderamento torna-se relevante por favorecer a compreensão de que, através da apropriação de aspectos da cultura dominante, pode-se vislumbrar a transformação da ordem social mais ampla.

Considerando-se que o poder opera, dialeticamente, como força positiva e negativa, ele opera, então, sobre e através dos indivíduos. Quando compreendem melhor a forma dialética como opera o poder nas relações sociais, econômicas e políticas, representantes das classes minoritárias podem perceber que ele não deve ser visto apenas como uma força negativa. Ele também está na base das mais diversas formas de comportamento de resistência e de luta por um futuro melhor (GIROUX, 1997).

Na luta pela equidade e justiça social, os alunos das classes sociais menos favorecidas, das quais é oriunda a maioria dos educandos da EJA, precisam ter acesso ao currículo dominante, pois isso pode lhes conferir maior poder de ação. Precisam, pois, adquirir um maior domínio da linguagem, compreendendo sua natureza dialógica, percebendo-a como portadora de valores axiológicos e identificando o caráter ideológico que lhe é inerente. Esses alunos precisam saber que o modo como pensamos e agimos no e sobre o mundo é determinado pela linguagem. Precisam, enfim, tomar consciência de que os usos da linguagem são sempre políticos, devendo esta ser investigada e percebida "como uma forma de disputa social” (MCLAREN, 2000, p. 29).

Nesse contexto, a importância do ensino e aprendizagem da linguagem justifica-se ainda mais, porque é por meio dela e através dela que se pode nomear a experiência e agir. Ela habilita o sujeito à interpretação de suas experiências, sendo também constitutiva de subjetividade, característica essencial para ele se posicionar discursivamente de forma reflexiva, historicizando o seu papel de agente social, como propõe McLaren (2000). Nessa linha de reflexão, é preciso considerar que a competência textual/discursiva torna-se uma forma de capital cultural ${ }^{1}$, cujo controle e acúmulo refletem relações assimétricas de poder, uma vez que sua distribuição é feita hierarquicamente. A esse respeito é importante que os usuários da língua percebam o texto

como uma forma desse capital, como uma realização de um poderoso ato de fala, como um modo de naturalizar e vulgarizar realidades sociais, como um instrumento de autoridade, e como o meio e a medida da disputa política (HANKS, 2008, p. 153).

A produção e a recepção de textos podem intervir na realidade social, à medida que podem alterar a compreensão das relações sociais. Como forma de ação, os gêneros materializados nos textos denotam uma capacidade potencial para produzir efeitos, gerando consequências na vida das pessoas, uma vez que, nesse processo de produção e de recepção de textos, os gêneros se constituem simultaneamente como produtos da ação e instrumentos para ela.

Nessa perspectiva, aprender a ler e a escrever na EJA exige a ruptura com um modelo tradicional de ensino, visando à ressignificação das práticas letradas desenvolvidas nas escolas, o que exige, por sua vez, a assunção de uma concepção de letramento capaz de formar os educandos para o efetivo exercício de cidadania, pois compreendemos que

[o]s estudantes precisam aprender a ler não como um processo de submissão à autoridade do texto, mas como um processo dialético de compreensão, de crítica e de transformação. Eles precisam escrever e reescrever as histórias nos textos que leem, de forma a serem capazes de identificar e desafiar, se for o caso, as maneiras pelas quais os textos funcionam ativamente para construir suas histórias e vozes (MCLAREN, 2000, p. 38).

\footnotetext{
${ }^{1} \mathrm{O}$ conceito de capital cultural, construído originalmente por Bourdieu (1987), refere-se às práticas de linguagem, à formação cultural, conhecimento, disposições e habilidades passadas de uma geração a outra. De acordo com Giroux (1997, p. 37), "também representa maneiras de falar, agir, andar, vestir e socializar que são institucionalizadas pela escola”.
} 
Um projeto de educação linguística de cunho emancipatório não pode prescindir de um aparato pedagógico crítico. Um projeto dessa natureza vincula-se aos fundamentos de uma pedagogia crítica, dialógica e resistente, acatando como legítimo o ponto de vista de que

[é] na arena do imaginário social que a pedagogia crítica, como uma forma de política cultural, pode realizar uma intervenção necessária. Ao reconhecer que os indivíduos são produzidos em meio ao embate entre discursos e posições de sujeito conflitivos, a pedagogia crítica pode ajudar-nos a interrogar criticamente tais discursos, permitindo que possamos desenvolver um sentido de "agência crítica" (MCLAREN, 2000, p. 38).

Atribuir cunho emancipatório ao letramento escolar implica instigar o aluno a problematizar as relações de poder, refletindo com ele sobre o modo como o poder opera na escola ou na sociedade mais ampla, silenciando-o nas práticas sociais das quais participa. Nesse processo, o educando necessita compreender que o seu silêncio pode resultar da "inabilidade" para dizer sua palavra, da falta de poder, ou seja, da "incapacidade" de agir e que essa compreensão resultará da sua condição de apreender e problematizar a realidade social.

Há tempo, a escola vem se queixando dos resultados precários obtidos na EJA, mas também se omitindo de desenvolver um currículo emancipatório, o que contribui para que o letramento dos educandos se dê de forma insatisfatória, tornando-os, muitas vezes, analfabetos funcionais, tolhidos de ação. Para agirem, os alunos, necessariamente, precisam refletir sobre como se processam as relações entre eles e seu entorno sociopolítico e cultural e como isso determina a constituição de sua identidade como agentes de letramento (KLEIMAN, 2006).

Entendemos, contudo, que combater o analfabetismo funcional é papel da escola que se propõe a formar para a cidadania. Instituir, então, formas de superar essa mazela torna-se essencial ao desenvolvimento cultural da nossa sociedade. A escola precisa, portanto, encontrar formas de ampliar as chances dos alunos de vivência com os princípios democráticos, pois esses alunos precisam compreender inclusive como ocorrem as relações assimétricas de poder em seu interior.

De acordo com Adorno (1995, p. 144), "quem deseja educar para a democracia precisa esclarecer com muita precisão as debilidades da mesma”. Para o autor, é necessário educar para a contradição e para a resistência, pois, efetivamente, só se pode imaginar uma democracia como uma sociedade emancipada. Considerar a possibilidade de se vivenciar práticas emancipatórias na escola implica empoderar o educando. Isso ocorre quando, por exemplo, se valorizam procedimentos de escuta, se instituem práticas e metodologias dialógicas, no intuito de contribuir com a autonomia dos educandos. Dito de outro modo, isso ocorre quando se ensina para o questionamento e para a reflexão crítica, favorecendo a conscientização dos educandos, gerada no âmbito de uma pedagogia radicalmente fundamentada e produzida na interface existente entre ação social, cultura e poder (GIROUX, 1983).

\section{GÊNERO DISCURSIVO E AGÊNCIA EM PROJETOS DE LETRAMENTO}

A exposição dos alunos à diversidade de gêneros discursivos gera mais possibilidades de apreensão das marcas textuais e enunciativas caracterizadoras desses gêneros bem como uma maior compreensão do seu modo de funcionamento na esfera social em que circulam. No trabalho com projetos desenvolvidos na perspectiva do letramento, não se deve seguir um planejamento que defina previamente os gêneros a serem trabalhados. Estes devem emergir no processo, para atender aos propósitos do grupo, já que a produção textual se insere em um contex to socialmente situado.

À medida que os alunos leem em diversos suportes (jornais, revistas, livros, sites, dicionários etc.), os gêneros discursivos vão se incorporando ao processo de ensino e aprendizagem com o fito de atender às necessidades interacionais do grupo. Dessa forma, os educandos ampliam o desenvolvimento de sua 
competência comunicativa em contextos mais aproximados de situações reais de uso da linguagem, com objetivos reais, embora se reconheçam como legítimas as situações de didatização do conhecimento trabalhado e produzido no contex to escolar.

Neste trabalho, por exemplo, para aprender como se configura um debate, os alunos precisaram organizar e vivenciar esse gênero, realizando-o na escola, mas ampliando o seu raio de alcance à comunidade do entorno. O debate, realizado na escola, cujo objetivo era discutir o voto como um dever ou um direito, proporcionou aos alunos uma oportunidade de ação para a mudança social. Vivenciando os diferentes papéis que estruturam esse gênero, quer seja debatendo, mediando ou participando como membro do auditório, os alunos puderam compreender melhor o processo de produção desse gênero; puderam perceber a importância da preparação prévia da enunciação de textos orais, à medida que aprendiam procedimentos para ancorar sua fala, orientando-a em função dos parâmetros da situação de comunicação e das especificidades do gênero.

É importante destacar que, para a realização de uma ação desse porte, foi preciso instrumentalizar o aluno para ampliar sua competência comunicativa na produção de textos argumentativos, oferecendo subsídios teóricos em duas oficinas realizadas com o grupo: uma sobre os elementos macroestruturais que, em geral, compõem os textos argumentativos, além de uma discussão acerca da importância da capacidade de argumentação para o exercício da cidadania e para a participação política; outra para trabalhar os aspectos formais e enunciativos do gênero em questão.

Uma maior reflexão sobre os procedimentos, estratégias e objetos de ensino trabalhados nos projetos de letramento permite afirmar que não se ensinam apenas os gêneros. Nesse processo, ensinam-se e aprendemse tantas outras coisas relevantes para a produção textual e para o conhecimento sobre os gêneros, que se pode dizer que esses artefatos não deveriam ser ensinados de forma prescritiva como se encontra nos PCN, privilegiando-se, normalmente, os seus aspectos formais. Eles deveriam ir sendo incorporados ao processo de ensino e aprendizagem, à medida que se vincula esse processo às vivências da prática cotidiana dos estudantes, para atender às suas necessidades, considerando seus interesses e seus propósitos comunicativos.

Ao se inserirem em atividades sociais, os gêneros emergem nesse processo, tornando-se ferramentas imprescindíveis às ações (de, com e sobre a linguagem) desses sujeitos. Desse modo, não se pode concebê-los tão-somente como formas textuais, uma vez que eles representam também formas de agir no mundo (BAZERMAN, 2006). É importante se considerar que "uma definição retoricamente válida de gênero precisa ser centrada não na substância ou na forma de discurso, mas na ação que é usada para sua realização" (MILLER, 2009, p. 22).

No trabalho em análise, as ações não se deram de forma aleatória. Apesar de haver flexibilidade no planejamento e a liberdade de adequação deste às necessidades do grupo, existiu uma planificação de todas as atividades desenvolvidas, na qual se levou em consideração o caráter agentivo da escrita e a pressuposição de que

se gênero representa ação, tem que envolver situação e motivo, uma vez que a ação humana, seja simbólica ou não, somente é interpretável num contexto de situação e através da atribuição de motivos (MILLER, 2009, p. 23).

No exemplo anteriormente discutido, o debate foi trabalhado não por estar previsto num planejamento previamente definido pela escola, mas por ser uma ação necessária aos interesses do grupo, dentre eles, o de sensibilizar a comunidade acerca da importância do voto no exercício de cidadania. $O$ gênero discursivo tornou-se um meio para a agência, materializando-se no debate, produção coletiva dos participantes do projeto, embora essa produção fosse também corporificada como ação individual de cada um dos agentes. 
O que se pode constatar é que a ação dos alunos nesse evento de letramento revelou que as estratégias utilizadas no processo de produção do gênero em análise mostraram-se suficientemente eficazes, seja para revelar o que os alunos traziam consigo de potencialidades, experiências e conhecimentos sobre esse gênero e outros mais, seja para mostrar-lhes que aquele objeto de estudo poderia se constituir em uma ferramenta para levá-los a outros domínios discursivos, como o da política, por exemplo.

A realização do debate mostrou-se importante para que os alunos percebessem que a fala varia. Algumas vezes, ela precisa ser muito bem planejada, diferentemente do falar informal produzido numa situação privada de uso da linguagem. Eles aprenderam, dentre outras coisas, que falar é algo que ocorre de acordo com os contextos, com as situações de comunicação e com os interlocutores. Nessa linha de raciocínio, a eles não foi ensinado apenas o gênero debate. Eles aprenderam a agir socialmente com ele e por ele, percebendo, assim, que as ideias podem provocar maior ou menor impacto no auditório. Aprenderam também que elas precisam necessariamente encontrar a forma falada ou escrita adequada para se materializarem nos discursos, isto é, os gêneros.

Pensando ainda o gênero como uma "ferramenta para descobrir os recursos que os alunos trazem consigo, ou seja, os gêneros que trazem de sua formação e de sua experiência na sociedade" (BAZERMAN, 2006, p. 31), destaca-se aqui a sugestão de uma aluna para a produção de alguns cartazes e faixas com o propósito de divulgar o debate e a campanha em defesa da participação política que havia sido deflagrada na escola.

Um momento como esse se torna especialmente oportuno para se focar as atividades do projeto na produção textual escrita, geralmente, uma das maiores dificuldades dos alunos, orientando-os e instrumentalizando-os para que produzam textos, observando, inclusive, o padrão monitorado da escrita. Em um projeto dessa natureza, experimentam-se novas estratégias, buscando-se alternativas para amenizar as dificuldades dos educandos. Por isso, foi proposta uma reunião para se avaliar o processo e deliberar coletivamente novas ações, já que, a cada dia, o projeto tendia a ampliar o raio de alcance das ações dele suscitadas.

Nessa reunião, a qual assumiu o caráter de uma sessão reflexiva em que se contou com a presença da maioria da turma, deliberou-se sobre a produção de cartazes e faixas para divulgar o debate que se realizaria na escola, mas seria aberto à comunidade escolar, e à comunidade do entorno. Nessa mesma ocasião, teve-se o cuidado de procurar saber se, no grupo, havia alguém com habilidades para o desenho, a pintura, a informática e a serigrafia. A intenção era não somente capitalizar recursos, mas também valorizar os talentos que pudessem ser mobilizados nas próximas ações do projeto, estimulando os potenciais individuais. Apenas a título de ilustração, apresentamos a seguir um dos cartazes esboçados, em sala de aula, para divulgar a campanha de participação política. Assim, vejamos:

Figura 1 - Cartaz produzido por aluno

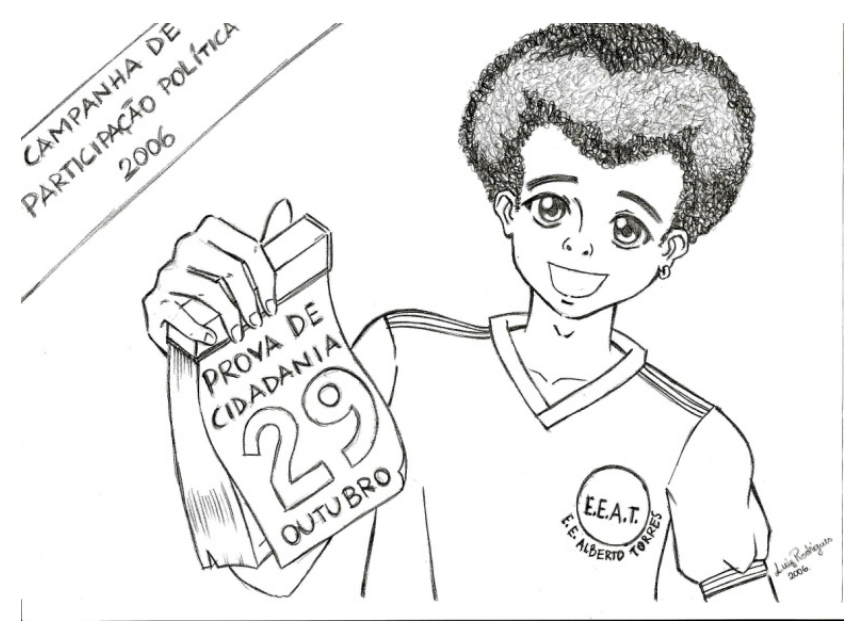

Fonte: Santos (2012). 
O cartaz esboçado acima revela tanto a competência discursiva do aluno produtor para usar a linguagem verbal quanto sua destreza e habilidade artística. Ao agendar a prova de cidadania para o dia da eleição, o aluno joga com uma expressão típica do discurso escolar, "a prova”, que adquire no contexto de produção do texto um sentido mais amplo, indo além do sentido habitual de avaliação do conteúdo escolar. O texto do aluno veicula o ponto de vista de que, ao votar, o eleitor dá uma prova ou demonstração de responsabilidade social e política com o gesto de cidadania. O cartaz produzido pelo aluno mostra a importância de se adotar uma perspectiva plural de letramento na escola, a qual possa incluir e valorizar o caráter multissemiótico dos textos lidos e produzidos pelos alunos, além de valorizar aspectos individuais no processo de letramento escolar.

A partir dessa atitude de valorizar mais os potenciais e as capacidades individuais, alunos que nem sempre participavam das atividades do projeto, engajaram-se de forma mais efetiva nas ações planificadas. Em decorrência disso, uma espécie de mutirão foi feito para a organização do debate. Nesse intuito, os alunos mobilizaram toda a escola e a comunidade do entorno na busca de recursos para a realização da mobilização, a qual se configurou como um "Pedágio de conscientização política". Para esse evento, eles buscaram inclusive patrocínio junto aos comerciantes locais para a compra do material necessário à produção das faixas, oportunidade em que convidavam essas pessoas a participarem do debate na escola. Parece ser oportuno destacar que outras ações foram desencadeadas, dentre elas a organização de um mural para a exposição do material pesquisado e lido ao longo do processo, tendo por fim contribuir com a formação de leitoresna escola.

Visando à formação do leitor crítico, organizou-se uma oficina de leitura de charges, gênero que se considera importante para o trabalho com os aspectos enunciativos do texto, através do qual os alunos podem apreender pontos de vista, valores axiológicos e visões de mundo, além da presença de diferentes linguagens e vozes sociais. Embora importantes, esses traços não serão aqui exaustivamente analisados em função do espaço exíguo deste artigo.

Após a realização dessa oficina de leitura, estimulados e motivados, os alunos que gostavam de desenhar produziram charges para serem publicadas no mural, já que nele constaria uma amostra significativa desse gênero, pois haviam lido durante o projeto muitas charges de diferentes autores, em diferentes suportes (jornais, revistas, sites etc.). A título de ilustração, apresenta-se abaixo uma das charges produzidas em sala de aula com o fito de ilustrar também a variedade de gêneros produzidos pelos alunos. Assim, vejamos a figura 2.

Observe-se a competência discursiva demonstrada pelo aluno na capacidade de entrecruzar linguagens e de mobilizar outras vozes sociais, que circulam nos textos lidos durante o projeto, para conferir autoridade ao seu discurso (BAKHTIN, 1990). Durante o período eleitoral de 2006, a mídia brasileira (impressa e falada) apontava escândalos de corrupção, enquanto mostrava que, geralmente, o então presidente Lula parecia querer se distanciar dos fatos, afirmando nada saber sobre eles. Ao produzir o seu próprio discurso, o aluno retoma a palavra do então presidente em exercício, Lula, profanando-a, quando o apresenta vestindo uma camisa de força.

A intenção do educando é, possivelmente, mostrar ao leitor que a negação dos fatos que circulam na esfera jornalística é uma "loucura". Para o educando era notória a preocupação de Lula com sua reeleição naquele contexto. Para reforçar esse ponto de vista, entrecruza a linguagem verbal e a não verbal para ratificar seu posicionamento. Observe-se que no avião está escrito "Reeleição 2006". O dinheiro "derramado" do avião presidencial, o Aerolula, cai exatamente no Palácio da Alvorada, sede do governo.

A partir da leitura do texto do aluno, apreende-se um tom apreciativo negativo dirigido à palavra alheia, ou seja, um tom de reprovação à afirmativa do presidente de que desconhecia os fatos noticiados na mídia, os quais apontavam indícios de corrupção por parte de alguns dos seus assessores. Além disso, valendo-se de elementos da linguagem não verbal, a auréola de santo, adorno usado na cabeça da personagem do 
presidente, o aluno veicula um ponto de vista, construído ironicamente, de que a auréola de santo não lhe era adequada.

Figura 2 - Charge produzida por aluno

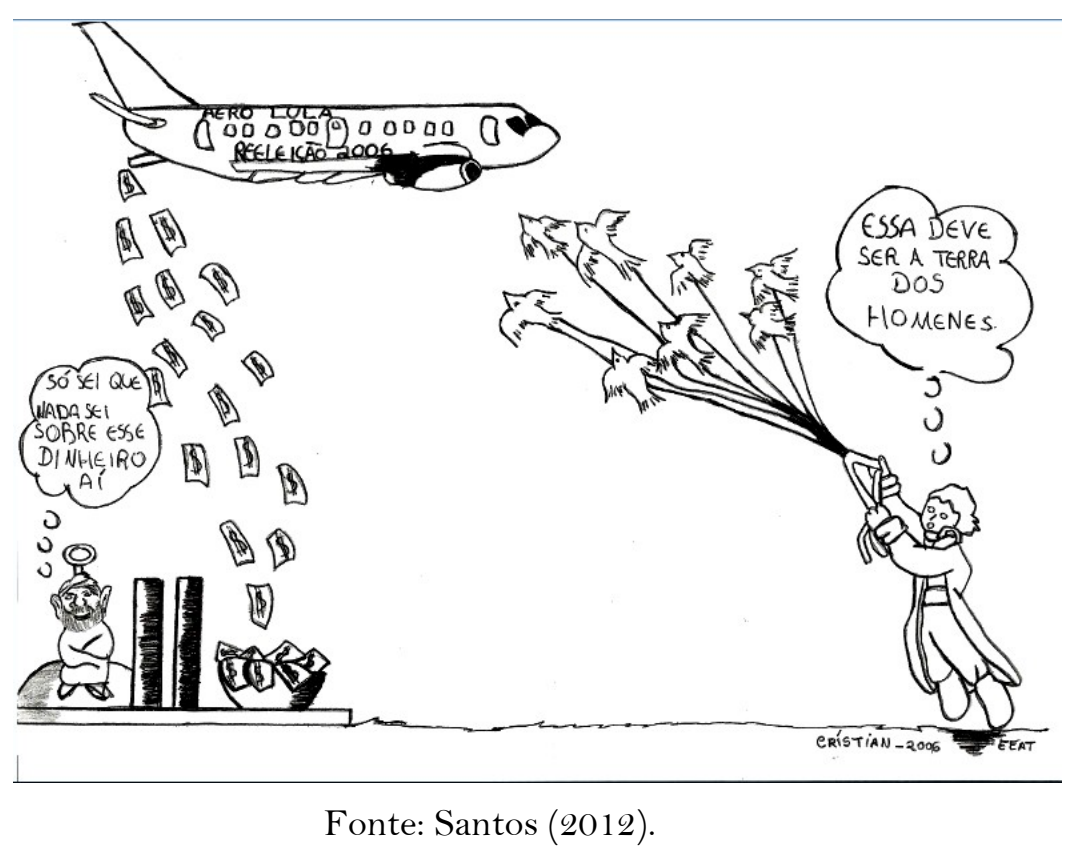

Observe-se a competência discursiva demonstrada pelo aluno na capacidade de entrecruzar linguagens e de

Ao expor juízos de valor e pontos de vista acerca desses fatos políticos, repudiando o comportamento do governante, o aluno constrói seu próprio discurso. É no processo de constituição de sua autoria que o educando se constitui identitariamente como agente de letramento, tendo o gênero discursivo (charge) como uma ferramenta para a ação sociopolítica. Nesse sentido, percebe-se a nítida imbricação entre autoria e agência, quando se põe em relevo o caráter agentivo da escrita, conforme propõe Bazerman (2006).

Por sua vez, no texto, o próprio presidente já construíra sua palavra, a partir do discurso de um filósofo grego, Sócrates, cuja frase "Só sei que nada sei” se tornou célebre. Podemos perceber, então, que o discurso do aluno dialoga com diversas vozes sociais. A partir dessas vozes reformuladas, foram construídos pontos de vista e veiculadas visões de mundo, tentando a adesão do leitor à causa assumida por eles, ou seja, à participação política.

Destaca-se ainda outro jogo intertextual, realizado pelo aluno ao inserir em seu texto palavras do escritor francês Antoine de Saint-Éxupèry, além da imagem que ilustra uma das obras mais conhecidas deste escritor, "O pequeno príncipe", a qual foi lida pelos alunos. É possível destacar que, no processo de produção do texto, o aluno mobilizou informações e recursos multissemióticos, advindos das suas experiências de leitura, quer sejam as do projeto, ou as da sua vida cotidiana.

Imerso em um processo de múltiplos letramentos, o aluno teve acesso aos livros "O pequeno príncipe" e "Terra dos homens", desse escritor francês, por meio de um "Círculo de Leitura" que ocorria simultaneamente às atividades do projeto. Essa atividade tinha por objetivo estimular a leitura como prática de entretenimento e oportunizar a experiência com a leitura do texto literário, com vistas a ampliar a competência leitora dos educandos. $\mathrm{O}$ círculo era mantido mediante o empréstimo de livros e filmes pertencentes ao acervo da biblioteca escolar e do nosso acervo pessoal ou dos alunos.

Durante o período do projeto, por sugestão do aluno produtor da charge, que havia lido esses dois livros do citado autor, o grupo inteiro teve a oportunidade de assistir ao filme "O pequeno príncipe", baseado na obra do escritor francês. Além disso, oportunizamos também a audição do CD cujo conteúdo era a contação da 
história lida pelo colega e assistida por todo o grupo. A charge acima apresentada resultou, portanto, de diferentes leituras, realizadas a partir de diferentes recursos, isto é, mediante uma abordagem multissemiótica do texto. Torna-se oportuno destacar que abordar o texto literário usando diferentes mídias foi uma experiência bastante enriquecedora, estimulando outros alunos a solicitarem o empréstimo do livro "O Pequeno Príncipe", que se tornou o mais lido do catálogo do "Círculo de leitura" naquele período.

Convém ressaltar que, no momento da realização da oficina de leitura de charges, embora os alunos tenham demonstrado gostar muito da experiência, não foi orientada a produção desse gênero. Em primeiro lugar, por se tratar de um gênero um tanto complexo, que exige do seu produtor um domínio sobre as habilidades artísticas necessárias ao uso das linguagens verbal e não verbal, entrecruzando-as num mesmo texto, algo que nem todos os alunos têm naturalmente. De qualquer modo, entende-se ser importante estimular o desenvolvimento de talentos, posto que, nas atividades, optou-se pelo conceito de letramento numa perspectiva plural. Ademais, considera-se como legítima a compreensão de que

[...] o talento não se encontra previamente configurado nos homens, mas que, em seu desenvolvimento, ele depende do desafio a que cada um é submetido. Isto quer dizer que é possível "conferir talento" a alguém. A partir disso, a possibilidade de levar cada um a "aprender por intermédio da motivação" converte-se numa forma particular do desenvolvimento da emancipação (ADORNO, 1995, p. 170).

Em segundo lugar, porque, se não havia um propósito definido para a circulação desses textos, não se justificaria a sua produção. Naquele momento, as charges produzidas possivelmente ficariam circunscritas à sala de aula. Nessa outra ocasião, a da organização do mural, elas teriam como destinatário a comunidade escolar, além de outros leitores, as pessoas que viessem à escola assistir ao debate. Revestindo-se do caráter agentivo que lhe é peculiar, as charges produzidas pelos alunos poderiam dar suporte às ações do grupo, contribuindo para formar a opinião dos leitores, à medida que veiculam pontos de vista e visões de mundo.

Trabalhado nas atividades de leitura com o propósito de formar o leitor crítico, o gênero charge cumpriu um importante papel social no trabalho realizado, considerando-se o seu propósito comunicativo e a motivação por que foi inserido nas atividades pedagógicas desenvolvidas. Consideramos oportuno destacar que a experiência com práticas de letramento na perspectiva multissemiótica permite aos alunos a construção de um discurso de empoderamento, o resgate da autoestima e a definiçãode identidades, sendo uma motivação a mais para a aprendizagem libertária.

Da imersão dos estudantes-agentes num turbilhão de gêneros que emergiram das práticas sociais e migraram para as práticas situadas do contexto escolar, resultam provas de que os alunos descobriram na escrita uma poderosa ferramenta para agir no mundo (BAZERMAN, 2006). Sentiram-se, por isso, chamados a agir, motivados por uma conscientização linguística crítica (IVANIC, 2004).

Imbuídos de agência e motivados para a ação, foi proposta pelo grupo a produção de uma carta cuja circulação dar-se-ia na véspera da eleição, sensibilizando o leitor sobre a importância e a necessidade de votar. $\mathrm{O}$ processo de produção desse gênero deu-se em várias etapas de escritura, inclusive, em algumas sessões de escrita colaborativa. Ao término da produção, os alunos solicitaram à direção da escola a reprodução do texto para ser distribuído em uma mobilização a ser previamente organizada com o apoio da comunidade escolar.

Apesar de a escola ter assumido o compromisso de reproduzir o documento, não o fez, tendo o grupo de redimensionar ações planificadas. Pensou-se, então, outro gênero cujo texto fosse mais curto, já que não se dispunha dos recursos materiais necessários à reprodução da carta aberta. Deixou-se que os próprios alunos buscassem alternativas para a resolução do problema. A partir do texto anterior, foi produzido um panfleto, assim denominado por assemelhar-se a um texto publicitário, cuja finalidade é divulgar algo; no caso, a divulgação da campanha de participação política na qual estavam envolvidos. 
Não se pode deixar de registrar certa dificuldade enfrentada pelo grupo para caracterizar e definir esse novo gênero. Atribuiu-se isso à relatividade de suas características, como propõe Bakhtin (2003). Essa compreensão pode ser substancialmente reforçada, numa perspectiva retórica, pelo entendimento de que a definição de gênero "não deve centrar-se na substância nem na forma do discurso, mas na ação em que ele aparecer para realizar-se” (MILLER, 2009, p. 151).

Pode-se dizer, portanto, que o novo texto originou-se tanto do tom panfletário que se havia assumido na carta aberta, anteriormente produzida pelo grupo, quanto do caráter de divulgação do anúncio publicitário, mas, naquela situação, assumiu o formato híbrido de um panfleto, gênero que se adequou ao motivo da ação engendrada pelo grupo.

\section{GÊNEROS DISCURSIVOS E DIALOGISMO}

Assumindo o gênero discursivo como ação social, optou-se por (re)pensar esse fenômeno - instrumento para a ação sociopolítica dos agentes envolvidos no projeto - a partir das suas funções agentivas, dos seus propósitos, dos seus interesses e das suas intenções. Apresenta-se, abaixo, como se configurou, empiricamente, o panfleto produzido pelos alunos.

Figura 3 - Panfleto produzido por alunos

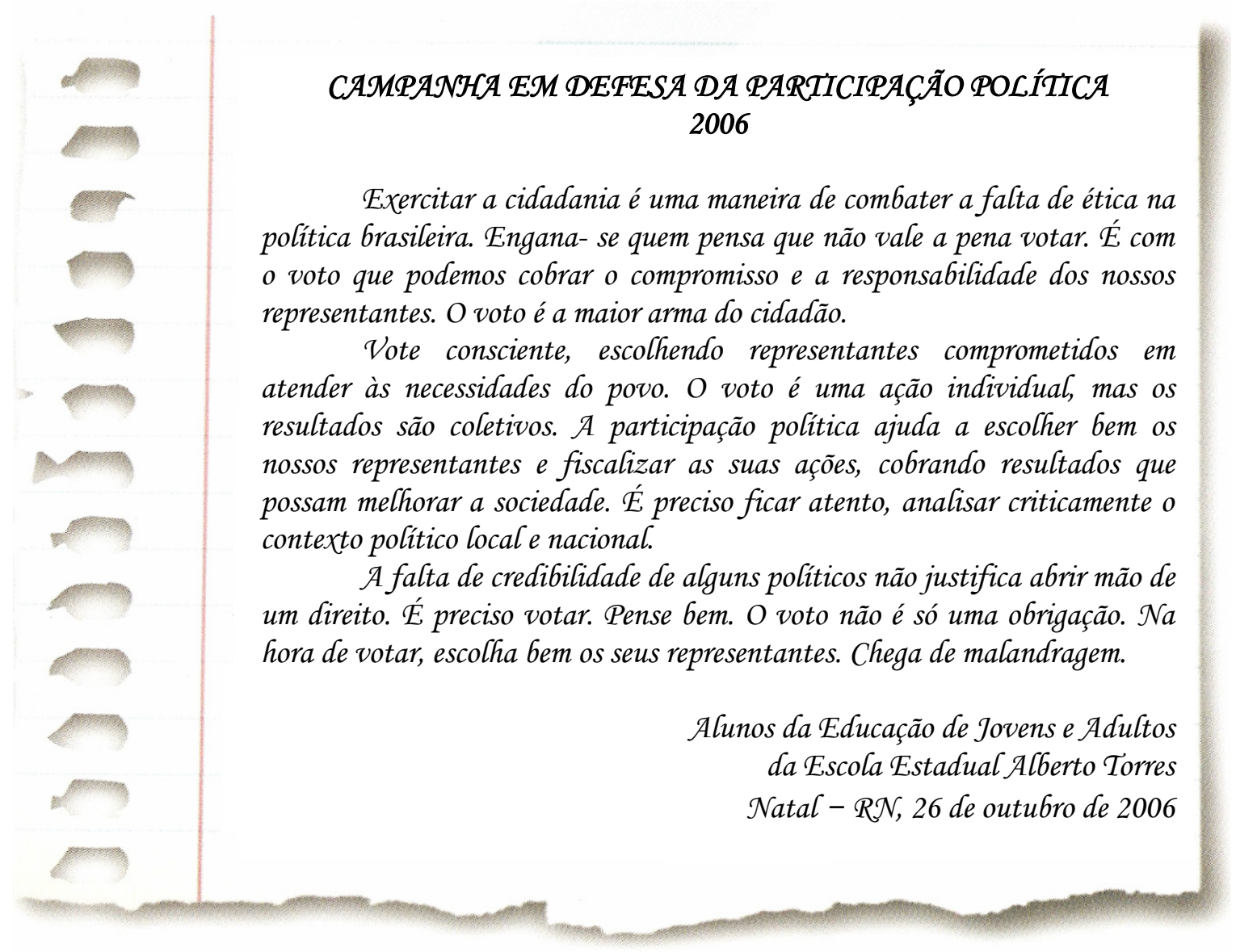

Fonte: Santos (2012)

Neste trabalho, não se tem o propósito de analisar minuciosamente as características formais do gênero apresentado, embora se torne evidente que os alunos demonstraram competências que vão além dessas características, à medida que se evidencia também a destreza desses no trato com os outros aspectos do gênero. 
Pretende-se aqui lançar um breve olhar sobre a relação sujeito-linguagem, observando a constituição dos alunos como sujeitos-agentes pelo que manifesta o seu discurso. Sendo assim, adotou-se a concepção de sujeito na perspectiva bakhtiniana, constituído de diferentes vozes sociais, que fazem dele um sujeito histórico e ideológico, cuja construção tem origem nas práticas discursivas, a partir da sua relação com o outro, de suas visões de mundo etc. Trata-se, enfim, de um sujeito produtor do seu próprio discurso ao articular, contrapor ou justapor as diversas vozes que emergem do seu discurso.

Partindo dos pressupostos de que o dialogismo é inerente à linguagem e de que se revela através das formas retóricas, observa-se, sucintamente, nesta análise como se revela a dialogicidade interna do discurso retórico dos alunos, como estes se apropriaram das vozes alheias e como revelam suas intenções, seus pontos de vista, seus valores, ou seja, como se constitui o círculo subjetivo dos locutores.

Pode-se ver que a designação do gênero dada pelos alunos não se deu por acaso. Certamente, eles perceberam no seu discurso um tom panfletário, em função do seu caráter tanto retórico, quanto político. Isso pode ser observado claramente nas estratégias utilizadas para convencer o interlocutor, no caso, os leitores.

A escrita dos alunos tem a intenção de formar a opinião do leitor (o eleitor) e de defender o seu ponto de vista, o de que é relevante votar, ou seja, é importante a participação política do cidadão. No dizer de Bazerman (2006), essa escrita está "imbuída de agência". Pode-se dizer que, ao produzi-la, os alunos pretendiam deliberadamente agir sobre um destinatário, o leitor/eleitor, além de agir sobre o mundo, transformando-o.

Percebe-se, no texto, uma posição assumidamente combativa e engajada desses sujeitos, colocando-os na condição de protagonistas estudantis, agentes voltados para a mudança social, à medida que protestam explicitamente contra a falta de ética na política brasileira e cobram compromisso e responsabilidade dos seus representantes, propondo a fiscalização das ações desses representantes.

No texto dos alunos, identifica-se não somente a assunção de pontos de vista. Reconhece-se também a defesa deles, sustentada em outras vozes que emergem dos jogos interativos que se estabelecem entre as muitas linguagens e os muitos discursos com que dialogam. Observe-se, por exemplo, a charge anteriormente apresentada, em que o aluno construiu seu discurso reformulando outros discursos que circularam na mesma época nos textos de jornais, revistas e até de livros que circularam em sala de aula. O discurso retórico deles é, portanto, um espaço fértil para a manifestação dessas vozes "alheias" em torno das quais as relações dialógicas são processadas.

Observe-se, ainda, um cruzamento de linguagens sociais, disputando espaço dentro de um mesmo enunciado. Quanto ao grau de formalismo, os alunos usam diferentes registros: o formal, o coloquial e até gíria, como, por exemplo, "chega de malandragem”. Esse cruzamento de linguagens que marca diferenças histórico-culturais e sociais, quando ocorre em um mesmo enunciado, proporciona o reencontro de duas consciências linguísticas separadas da língua, quer seja por uma diferença de época, quer seja por uma diferença social ou por ambas. A esse fenômeno Bakhtin (1990) deu o nome de hibridização.

Cumpre ressaltar que, durante o processo de reescritura do panfleto, discutiu-se a adequação da expressão "chega de malandragem", mas alguns alunos insistiram em mantê-la no texto, alegando que essa era uma forma mais impactante de mostrar ao eleitor o que pensavam dos políticos desonestos e antiéticos. Resolveu-se, assim, conservá-la no texto, respeitando o direito dos alunos de dizerem sua palavra sem se submeterem facilmente aos ditames de uso da língua padrão. Considerou-se também que mantê-la no texto não comprometeria a eficácia da ação sociopolítica engendrada pelo gênero.

Ademais, numa situação de conflito diglóssico, diante da complexidade que é aprender a variante padrão da língua, torna-se imprescindível que se tenha cautela e, principalmente, respeito pela fala do educando. 
Acerca dessa problemática, tornam-se por demais relevantes e oportunas as contribuições de Kleiman (2012, p. 35) ao postular:

A tarefa de aprender uma variante diferente é enorme. Também é enorme a tarefa de reverter a situação dos dominados na situação de conflito diglóssico. A escola tem o dever de mudar a percepção da sociedade sobre o que está envolvido na aprendizagem de um segundo dialeto. A prática tradicional da escola, muitas vezes, sem perceber e com as melhores intenções de "ensinar a norma padrão", acaba por excluir também de suas próprias práticas os alunos que não conhecem essa norma ou suas variantes de prestígio.

No ensino da língua materna, embora se reconheça ser importante o domínio das diversas variantes linguísticas e que a variante padrão pode subsidiar o engajamento dos educandos no diálogo com a sociedade mais ampla, não se pode impor ao aluno o uso dessa norma sob a falsa ideia de que o domínio dela é o único meio de acesso à cultura escrita, aos bens culturais e à inclusão social. Cabe à escola desenvolver no educando a motivação necessária à aprendizagem dessa variante, sem ser necessário desprezar seu próprio capital cultural.

Mostrando-lhe quando e por que ela se faz necessária em determinadas situações de uso da linguagem, a escola pode levar o educando a melhor compreender o porquê de aprendê-la. Dessa forma, o ensino e a aprendizagem da norma padrão adquire sentido para ele. É preciso se considerar que, na luta pela legitimação da escrita dos grupos socialmente excluídos, deve ser dada bastante importância à voz do educando no contexto escolar. O direito à voz é condição indispensável à sua formação cidadã. Por isso, comunga-se com o ponto de vista de que

[o]s educadores jamais devem permitir que a voz dos alunos seja silenciada por uma legitimação deformada da língua padrão. A voz dos alunos jamais deve ser sacrificada, uma vez que ela é o único meio pelo qual eles dão sentido à própria experiência no mundo (FREIRE; MACEDO, 1990, p. 100).

A partir dessa visão epistemológica, buscou-se compreender os textos produzidos pelos educandos respeitando as formas por eles escolhidas para dizerem sua palavra. Investigou-se, então, o sentido que emana de suas palavras naquilo que enunciam, observando-se os propósitos comunicativos que norteavam sua escrita. Assim, percebeu-se, por exemplo, que o uso da expressão "Chega de malandragem" e de outras como "o voto é a arma do cidadão" pode, sob uma determinada perspectiva mais reducionista, representar apenas um lugar comum no texto dos alunos. Na perspectiva enunciativa, pode revelar que, na arena em que se luta usando a linguagem, constrói-se um discurso específico, próprio de um determinado estrato social, podendo este ser vinculado à classe, à idade ou à profissão de quem enuncia, discurso esse que se localiza no tempo e no espaço (BAKHTIN, 1990). Para Bakhtin, através desse fenômeno, as línguas evoluem, ampliam-se e transformam as formas de ver e compreender o mundo. Em uma mesma e única língua nacional, ocorre a orientação dialógica interna do discurso entre línguas sociais diversas.

$\mathrm{Na}$ análise dos textos dos alunos, percebeu-se, de um modo geral, que as escolhas linguísticas feitas por eles tendem a considerar o padrão culto da língua, revelando por parte dos produtores, uma preocupação com o seu ouvinte/leitor. Essa postura parece indicar não apenas que eles estão "se familiarizando" com a noção de escrita como uma prática social, inserida numa comunidade discursiva com regras e propósitos estabelecidos dentro dessa comunidade, mas também que reconhecem o valor social desta variedade de uso da língua.

Também é possível observar, no discurso dos alunos, a ocorrência de uma compreensão responsiva ativa deles em relação aos textos lidos com os quais interagiram antes ou durante o desenvolvimento do projeto. Segundo Bakhtin (1992, p. 314), "as palavras dos outros introduzem no nosso enunciado sua própria expressividade, seu tom valorativo, que assimilamos, reestruturamos, modificamos".

Nessa perspectiva dialógica da linguagem, pode-se entender que o enunciado dos educandos constitui-se como uma resposta a um já-dito sobre o mesmo tema. A escrita deles está inevitavelmente marcada pela 
heterogeneidade discursiva, fenômeno constitutivo da linguagem. Naquilo que enunciam, revela-se o diálogo entre diferentes vozes sociais (do senso comum, da política, da ética etc.). Como locutores, os alunos fazem emergir no seu discurso o já-dito do senso comum, que dessacraliza a imagem dos políticos, nivelando-os a "bandidos".

Ao enunciarem "Engana-se quem pensa que não vale à pena votar", observa-se que o discurso deles emerge de uma tensão dialógica do discurso alheio e, ao constituir-se, participa do diálogo social, iluminando/obscurecendo seu objeto pelas vozes sociais, pela heteroglossia dialógica. Pode-se perceber que os locutores não se comportaram como sujeitos passivos diante dessas vozes.

A réplica desses sujeitos é uma resposta antecipada, remetendo a orientação discursiva para o ouvinte/leitor. Observemos um fato curioso: esses sujeitos produtores do discurso simulam uma estratégia de distanciamento do conteúdo do seu dizer, atribuindo-o a outra voz, uma mesma voz que funciona como suporte para o seu dizer. Ao mesmo tempo, apresentam o seu ponto de vista - vale a pena votar. Usando a linguagem como meio de interação social, os sujeitos apreendem a realidade, o que pode ser percebido nessa réplica.

Considerando o que nos diz Bakhtin (1990, p. 201), "toda linguagem é um ponto de vista, uma perspectiva sócio-ideológica dos grupos sociais e dos seus representantes personificados", o posicionamento dos alunos em relação ao tema abordado configura-se perfeitamente como uma antecipação deles à resposta do outro.

Na perspectiva bakhtiniana, o discurso é sempre orientado para uma resposta que o influencia e a esta se antecipa. Essa orientação para o ouvinte/leitor deve ser percebida como orientação para um horizonte conceitual específico, para o mundo específico do ouvinte/leitor, que é visto como um sujeito dotado de uma compreensão responsiva ativa, que representa uma força dentro do enunciado, participando do discurso. Nesse sentido, observamos que, ao produzirem o seu enunciado, os alunos consideraram não só o interlocutor deles, o sujeito com o qual dialogam mas também perceberam o importante papel que este desempenha na sua enunciação, tratando-o como um elemento constitutivo dela.

O significado do enunciado dos alunos é compreendido em meio a outros enunciados que abordam um mesmo tema. Por isso, ele é prenhe de valores, de visões de mundo e de pontos de vista. O dialogismo daí resultante enquadra-se numa perspectiva mais subjetiva, mais psicológica, uma vez que nele ressoam as crenças subjetivas do outro, por sua vez impregnadas de valores axiológicos, razão pela qual esse significado não pode ser percebido apenas como significado linguístico.

De acordo com Bakhtin (2003), a relação dialógica não tem existência no sistema linguístico, ela é uma relação de sentido estabelecida entre enunciados, pois o sistema linguístico apresenta apenas um caráter potencial, mas a relação com o sentido é sempre dialógica e este se distribui entre as diferentes vozes, por isso a concepção de dialogismo formulada por este autor contempla o diálogo numa perspectiva bem ampla, para além da discussão, da polêmica e da paródia.

Assim, confirma-se a tese bakhtiniana de que o centro organizador da enunciação é o exterior. Este se situa no meio social onde o indivíduo está inserido (BAKHTIN, 2003). Sendo assim, observa-se que os alunos lançaram mão de diversas vozes que circulam na sociedade, como vimos anteriormente, e isto se torna evidente no seguinte trecho "a falta de ética de alguns políticos não justifica abrir mão de um direito". É importante notar que, embora concordem parcialmente com a voz que diz que os políticos brasileiros não têm ética, os alunos emitem suas visões de mundo e seus juízos de valor sobre a atividade desses políticos, levando o leitor a perceber que não são todos que não têm ética, mas apenas "alguns políticos".

Ao se anteciparem à resposta do ouvinte/leitor, os alunos profanam a palavra autoritária alheia - os políticos não têm ética - para, no processo de construção de sua própria palavra, torná-la interiormente persuasiva, dialogizando internamente o seu discurso. Na concepção bakhtiniana, ao internalizar as palavras 
do outro, o locutor transforma-as em palavras dele, as quais adquirem um sentido profundo na sua formação ideológica. Dessa forma, sustentam uma atitude ideológica frente ao mundo e definem seu comportamento ao emergirem como palavras autoritárias e como palavras interiormente persuasivas (BAKHTIN, 1990).

Em certa medida, os alunos desconstroem a visão generalizada de que todos os políticos brasileiros não têm ética, buscando fortalecer o seu discurso retórico, reforçando a defesa do seu ponto de vista, o de que "é preciso votar". Na concepção desses alunos, é preciso saber escolher os seus representantes para "votar certo". Para reforçar seu ponto de vista, argumentam que "o voto não é só uma obrigação". Embora seja obrigatório no Brasil, para eles o voto é também um direito, podendo ser usado para mudar a realidade política do país, para combater a "malandragem" dos políticos e, consequentemente, para a mudança social.

\section{A ESCRITA COMO PRÁTICA DISCURSIVA E SOCIOPOLÍTICA}

Conforme observamos, nas palavras ressoam vozes. Na perspectiva bakhtiniana, até o silêncio é dialógico. Por isso, Bakhtin/Volochinov (2000) sinaliza que, para um trabalho mais produtivo com a língua, não podemos desconsiderar a palavra isolada da voz, apenas a palavra da pessoa, porque

em cada palavra há vozes que podem ser infinitamente longínquas, anônimas, quase despersonalizadas (a voz das matrizes lexicais, dos estilos etc.), inapreensíveis, e vozes próximas que soam simultaneamente (BAKHTIN/ VOLOCHINOV, 2000, p. 353).

Em síntese, sob esse prisma, até o silêncio é dialógico. Ancorando-se numa concepção dialógica da linguagem, neste trabalho, a escrita assume em primeiro lugar o caráter de prática discursiva e, em segundo lugar, o caráter de uma prática sociopolítica (IVANIC, 2004). No primeiro caso, a aprendizagem da escrita se dá de forma socialmente situada, considerando objetivos especificamente pensados, que contemplam a situação de comunicação. Na produção de texto, leva-se em conta todo o processo e não apenas o produto final, embora produto e processo apresentem-se imbricados.

Nessa concepção de escrita, os alunos não se limitam a aprender os aspectos linguísticos do texto, porque estão inseridos em uma comunidade de prática, a qual, no âmbito da educação, vincula-se a uma comunidade de aprendizagem (WENGER, 1998). Nesse modelo de aprendizagem, o conhecimento não pode ser visto de forma descontextualizada, abstrata ou geral. A aprendizagem é situada, ocorrendo "numa atividade, numa cultura e num contexto específico, realizando-se, assim, na interação, num processo de coparticipação social" (OLIVEIRA, 2008, p. 109).

Nessa abordagem, os alunos aprendem a escrever através da participação em eventos socialmente situados e com objetivos claramente definidos. Eles aprendem à medida que melhor compreendem a forma de organização da situação comunicativa e os elementos constitutivos dela, quando a escrita passa a ser concebida como uma série de práticas sociais que se constituem a partir de

padrões de participação, preferências de gênero social, redes de apoio e colaboração, padrões de uso do tempo, espaço, ferramentas, tecnologia e recursos, a interação entre a língua escrita com outros modos semióticos, os significados simbólicos do letramento e os objetivos sociais mais amplos que a escrita desempenha na vida dos indivíduos e das instituições (IVANIC, 2004, p. 12).

Partindo dessa concepção de prática social, a escrita é estudada a partir dos seus usos e formas, considerando tanto seus aspectos linguísticos, quanto os discursivos e oferecendo subsídios para que os alunos tenham condições efetivas de usar a palavra escrita para agir discursivamente. Nessa perspectiva, as práticas de letramento são moldadas a partir de uma visão de linguagem/discurso como prática social, isto é, como um modo de ação no mundo (FAIRCLOUGH, 2001) que se dá numa relação dialética com a estrutura social. Sob esse prisma, compreende-se que a prática social intervém na vida social em seus vários 
domínios (econômico, cultural, político etc.), estabelecendo relações com outras práticas (CHOULIARAKI; FAIRCLOUGH, 1999).

No caso desses alunos, pode-se dizer que, como sujeitos agentes, foram capazes "de realizar suas próprias conexões entre diversas práticas e ideologias às quais são expostas" (FAIRCLOUGH, 2001, p. 121). O seu discurso chegou efetivamente a outras esferas sociais, com as quais estabeleceram relações dialógicas, conforme se pode observar na resposta dada por uma instituição a um dos textos produzidos na esfera escolar. Assim, vejamos.

Acompanhando a mobilização realizada nas imediações da escola, um juiz eleitoral que circulava como qualquer um dos transeuntes, ao receber das mãos dos alunos o panfleto, procurou informar-se melhor sobre o projeto e propôs ao Tribunal Regional Eleitoral do RN (TRE) um voto de louvor à escola pela realização de um projeto voltado, especificamente, para o letramento cívico dos alunos. O fato de ver o reconhecimento do seu trabalho pelo órgão maior do poder judiciário, responsável pelo processo eleitoral no estado, fez os alunos perceberem claramente o impacto do letramento na vida deles, bem como o impacto que sua escrita causou em pessoas pertencentes à outra esfera de atividade, no caso, a jurídica, favorecendo a interação entre diferentes esferas sociais (a escolar e a jurídica).

Pode-se afirmar que, a partir do trabalho com projetos de letramento, a escrita dos educandos atingiu objetivos sociais mais amplos, transpondo os muros da escola. Ao chegar à esfera escolar, a escrita do judiciário, por sua vez, também provocou um grande impacto nos membros daquela comunidade. Motivados à ação sociopolítica mediada pela escrita, alunos da EJA podem se tornar mais empoderados, ganhando maior autonomia e maiores chances de emancipação.

O voto de louvor, aprovado por unanimidade pela Procuradoria Regional Eleitoral do RN e pelo TRE, comprova que os alunos aprenderam a usar a escrita para legitimar sua cidadania. Num processo de ensino e aprendizagem dessa natureza, a produção textual escrita configura-se efetivamente como uma atividade discursiva cujas palavras comportam em si um tom apreciativo, expresso nos pontos de vista, nas visões de mundo e nos valores axiológicos que emitem.

Nessa perspectiva, a palavra escrita tornou-se o território comum entre os alunos e os seus interlocutores e vice-versa. Como um fenômeno dialógico e ideológico por excelência, ela é o produto da interação de sujeitos sócio-históricos que se definem em relação à coletividade, razão pela qual Bakhtin/Volochinov (2000, p. 113) afirma: "a palavra é uma espécie de ponte lançada entre mim e os outros". Nesta experiência, constata-se que o trabalho com projetos de letramento pode favorecer a circulação social dos textos dos educandos. A escrita deles estabeleceu "uma ponte" entre o discurso deles e outros discursos que circulam para alémdos muros escolares. Usando a linguagem como prática social, eles puderam "agir sobre o mundo e sobre os outros" (FAIRCLOUGH, 2001, p. 91), construindo relações sociais com outras pessoas, de outras esferas de atividade. Assim, vejamos a figura 4.

A partir da leitura do gráfico, pode-se perceber que o texto dos alunos, embora produzido na sala de aula, não ficou aí aprisionado. Ele circulou na escola, mas também foi além de suas fronteiras. Inseridos num processo de letramento cívico (SANTOS, 2012), os educandos foram pouco a pouco se transformando em agentes sociais efetivos, à medida que adquiriam autonomia tanto para sugerir ou escolher os gêneros lidos e produzidos quanto para selecionar o que dizer, formas de dizer, quando dizer ou a quem dizer sua palavra. Nessa linha de reflexão, é possível afirmar que os projetos de letramento configuram-se como "projetos de dizer", no sentido de que eles favorecem o desenvolvimento da capacidade comunicativa dos sujeitos, quer seja para falar quer seja para escrever.

\footnotetext{
${ }^{2} \mathrm{~A}$ noção de Projeto de dizer aqui apresentada é devida a Bakhtin (2003), para quem o tex to é compreendido como enunciado que não se circunscreve à materialidade do texto. Pressupõe um autor, um interlocutor, uma compreensão responsiva ativa em relação ao outro, um "projeto de dizer". Em função dessa compreensão responsiva do outro é que o autor dá sentido e acabamento ao que enuncia.
} 
À proporção que os alunos desenvolviam uma maior conscientização linguística crítica (FAIRCLOUGH, 2001), expandiam-se os potenciais de agência e de protagonismo estudantil deles. Isso os estimulava cada vez mais aos questionamentos e às contestações, razão pela qual se sentiam encorajados e motivados a contribuir com as mudanças sociais que desejavam ver. Esses sujeitos adquiriram também, ao longo do processo, empoderamento a cada evento de escrita. Regulada por forças sociais e relações de poder, esta prática participa da construção de forças que atuarão na dialética entre o passado, o presente e o futuro desses agentes (FAIRCLOUGH, 2001).

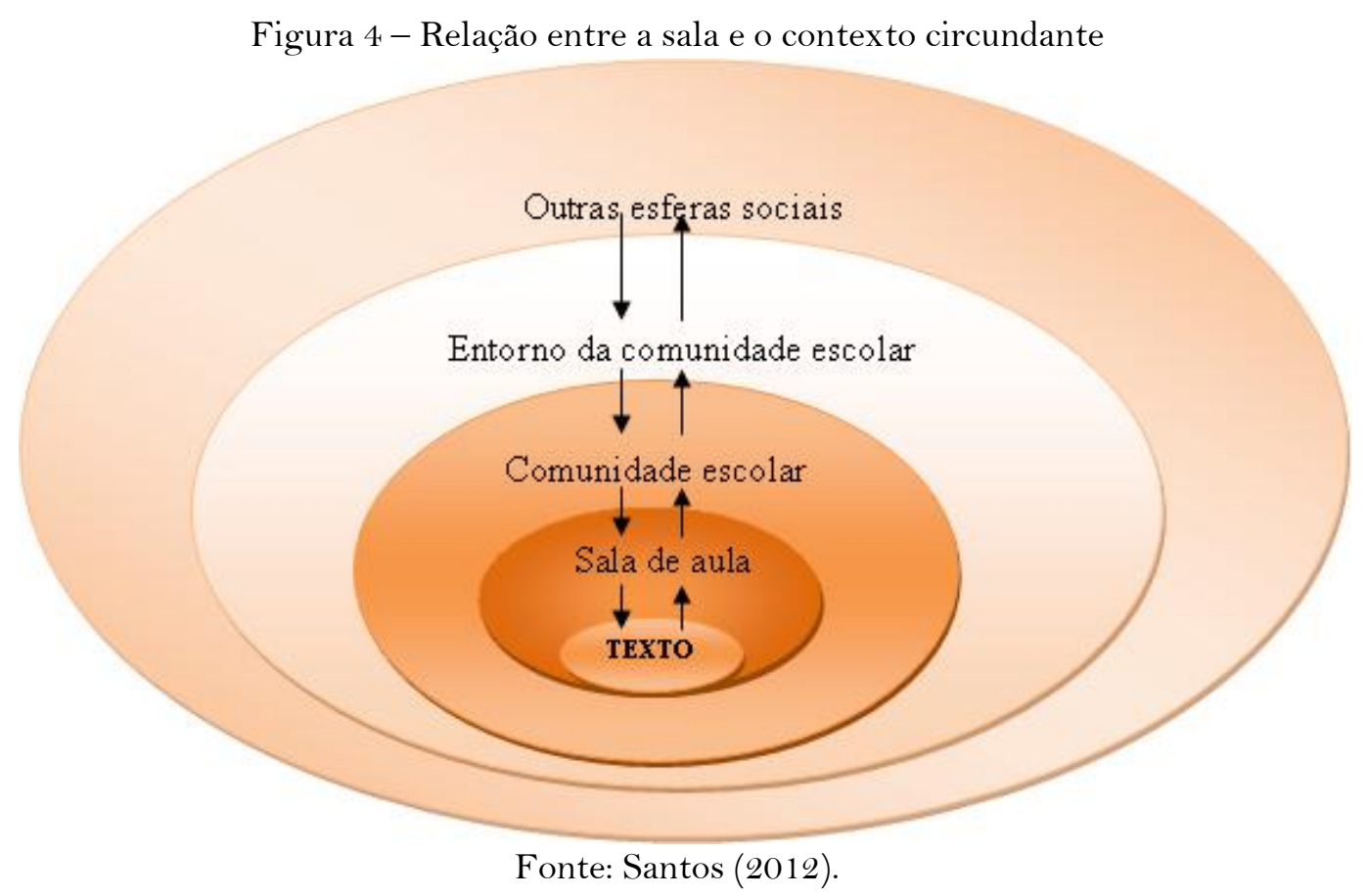

As consequências desse empoderamento eram percebidas tanto pelo modo como os alunos atuavam na comunidade discursiva na qual eles estavam inseridos, quanto pela forma como assumiam verdadeiramente sua identidade de estudantes agentes de letramento (KLEIMAN, 2006). Torna-se oportuno destacar que esses alunos atuavam em uma comunidade de aprendizagem que favorecia a equidade e a emancipação dos seus membros e que propiciava as habilidades de pensamento e de resolução de problemas dentro e fora da escola, conforme podemos verificar nas palavras de uma das participantes ao avaliar as suas vivências no projeto de letramento ora apresentado:

[…] nós trabalhamos muito mesmo. Foi bom demais! mas depois foi muito melhor, quando vimos o nosso trabalho ser reconhecido pelas autoridades do TRE. O louvor que recebemos é também seu. Sentimos muito orgulho disso tudo e de todos nós. [...] Outra coisa maravilhosa do projeto foi escrever para o jornal pedindo ajuda para resolver nossos problemas da comunidade. Além de tudo ainda escrevemos para a Câmara Municipal pedindo solução para o problema da violência do bairro. [...] Aprendi a escrever de verdade. Gostei de produzir e de ler textos de muitos gêneros. [...] Foram tantas coisas que aprendi a gostar de ler e escrever. Agora sei o que é realmente cidadania.

Nas palavras da aluna, percebe-se a sua satisfação com o trabalho vivenciado. No projeto de letramento, as atividades escolares tornaram-se autênticas porque estavam vinculadas à vida e, por isso, mais atraentes aos olhos dos alunos, que não eram meros participantes, mas efetivos agentes no processo de ensino e aprendizagem. Nessa perspectiva situada de ensino, as práticas de letramento desenvolvidas na escola foram ressignificadas. Os alunos se tornaram sujeitos-agentes, construtores de sua cidadania.

Percebe-se, assim, que o engajamento dos educandos em atividades que não se circunscrevem à esfera escolar lhes permite compreender melhor sua realidade social e vislumbrar possibilidadesde transformação e mudança social dessa realidade. Sob esse viés, o ensino da leitura e da escrita contribui para engendrar vivências com práticas cidadãs no contexto escolar, favorecendo ao aluno a oportunidade de perceber a 
cidadania como algo construído com a participação efetiva dele. Nesse sentido, é importante que ele tenha clareza de que

cidadania é algo que se constrói somente a partir do engajamento cívico, isto é, da ação recíproca do homem motivado por propósitos comuns e pela vontade de crescer em comunhão. Essa parece ser a função maior do processo educativo. (OLIVEIRA; TINOCO; SANTOS, 2011, p. 37).

Como afirma a aluna, eles construíram-se cidadãos à proporção que assumiram uma postura crítica, reflexiva e, sobretudo, engajada. Mediante o trabalho com projetos de letramento, os alunos atuaram ativamente na construção, negociação, intervenção e transformação do mundo social (BARTON; HAMILTON; IVANIC, 2000). Fundamentados na interação, no diálogo, na reflexão conjunta e no compromisso de atingirem objetivos comuns de aprendizagem, desenvolveram as capacidades de análise e crítica, habilidades imprescindíveis à compreensão e à transformação da realidade sociocultural e política em que se inserem.

No desenvolvimento do projeto, os alunos vivenciaram eventos de letramento que lhes oportunizaram reconhecer a função interativa da escrita, capaz de inseri-los em outros mundos de letramentos e em outras esferas de atividade, tais como a do judiciário, a do jornalismo e a do legislativo, por exemplo, em cujos espaços buscaram a solução para problemas por eles enfrentados.

Além disso, como construção cultural, a escrita desses alunos mostrou-se útil para registrar suas experiências, os acontecimentos e as representações construídas acerca do trabalho realizado no projeto, mostrando-o como funcional, relevante e significativo para o desenvolvimento do letramento plural desses sujeitos.

Como meio de recriar a cultura, a escrita deles mostrou-se proveitosa também para a construção de diferentes interpretações da realidade pessoal, social, cultural e política (PÉREZ; GARCÍA, 2001), pois lhes permitiu descobrir as relações existentes entre os fatos e acontecimentos no contexto de uma sociedade democrática, plural e mutante.

\section{CONSIDERAÇÕES FINAIS}

Neste trabalho, refletindo sobre experiências de ensino de língua materna na EJA, vivenciadas a partir do desenvolvimento de projetos de letramento, discutiu-se a importância de se deslocar o processo de leitura e de escrita para além dos muros da escola, trabalhando essas práticas na perspectiva do letramento como fenômeno plural, crítico e político. Sendo assim, defendeu-se uma abordagem dos textos (orais e escritos), considerando-os na perspectiva das práticas discursivas. Evidenciou-se a necessidade de se considerar, na urdidura desses textos, o desvelamento dos propósitos, das intenções e das ideologias que neles se manifestam, contemplando os aspectos enunciativos dos textos lidos e produzidos em sala de aula, isto é, indo além dos seus aspectos estruturais, conforme propõe Santos (2004).

A experiência com projetos de letramento apontou que, quando se trabalham os aspectos enunciativos do texto, ampliam-se os potenciais de autoria dos alunos, podendo-se, assim, oferecer mais subsídios para o desenvolvimento da capacidade de agência cívica dos educandos. O trabalho desenvolvido com esse tipo de projeto apontou a necessidade de uma compreensão mais ampla do papel do gênero discursivo no ensino da língua. Entende-se que a escola precisa se desvencilhar da concepção reducionista de que deve trabalhar sobre os gêneros. Para isso, ela precisa compreender que tratá-los como objeto de ensino, desconsiderando a prática, isto é, limitando-se ao ensino puramente pela forma, é um equívoco. É necessáriose considerar o gênero discursivo em uma perspectiva mais ampla, como uma categoria da linguagem, sem associá-lo exclusivamente ao texto, conforme ainda ocorre em muitas escolas. 
Se a concepção que se assume na escola é a de que ensinar o gênero é limitar-se aos seus aspectos formais, talvez, não seja necessário ensiná-lo. Nessa perspectiva reducionista em que predomina o ensino da forma, não se ensina nem o texto nem o gênero. $\mathrm{O}$ importante é ensinar o aluno a usá-lo para atender às suas necessidades de participação social e política. Nessa perspectiva, ampliam-se as possibilidades de formar educandos mais empoderados e emancipados. No processo de letramento cívico, o trabalho com os gêneros discursivos se torna especialmente importante para orientar as atividades didático-pedagógicas. Eles se tornam ferramentas indispensáveis às ações dos agentes de letramento (professores e alunos), pois não se reduzem meramente a formas textuais, uma vez que representam formas de vida e de ação (BAZERMAN, 2006).

Nos projetos de letramento, os gêneros discursivos são considerados como objetos do saber, mas também do saber-fazer, o que exige uma formação adequada de todos os agentes neles envolvidos. A diversidade de ações de linguagem realizadas nesses projetos resulta da ação efetiva e da participação social e política desses agentes, cujo processo educativo imprime maior legitimidade e empoderamento à sua escrita, fortalecendo neles sua condição de cidadãos. Nesse sentido, os gêneros discursivos assumem, especialmente, nesse tipo de projeto, o papel de ferramentas para a ação sociopolítica dos seus colaboradores, potencializando o caráter agentivo de sua escrita, para que possam atingir metas e objetivos traçados na busca de resolução dos problemas desses agentes, naquilo que concerne à vivência da cidadania plena.

$\mathrm{Na}$ sociedade democrática em que estão inseridos, os educandos precisam saber que fazer política, atualmente, é, principalmente, saber agir nas mais diversas esferas sociais. Por isso, eles precisam se inserir em diferentes comunidades de escrita. Centrar o processo educativo na interação desses agentes, considerando as potencialidades, as experiências e os fundos de conhecimento de cada um, permitiu, nesta experiência, a ressignificação do ensino da língua materna na EJA, possibilitando que a construção do conhecimento se desse de forma significativa para os alunos.

É necessário desenvolver metodologias dialógicas na EJA, contudo é preciso que se tenha clareza de que empreender a construção de um fazer pedagógico dessa natureza exige dos professores, além dos fundamentos necessários, a assunção de responsabilidade moral e política para construir relações sociais de equidade em que todos se construam coletiva e solidariamente cidadãos, capazes de remodelar democraticamente a sociedade atual.

Para o alcance dos objetivos de ensino da língua materna e a consecução de metas e objetivos traçados nas políticas públicas destinadas à educação popular em nosso país, considera-se relevante, em termos de formação docente, que se dê aos professores o suporte necessário para romper com o artificialismo comumente imposto às práticas pedagógicas desenvolvidas nas salas de aula da EJA, a fim de que possam imprimir novos sentidos ao processo de letramento escolar. Da parte do professor, faz-se necessária, antes de tudo, a assunção de uma postura crítica, reflexiva e engajada, comprometida com o ideal de formar sujeitos-agentes, construtores de sua cidadania.

Alcançar metas e objetivos traçados para a escolarização de jovens e adultos, no Brasil, requer uma maior reflexão acerca do que significa educar para a cidadania. Garantir aos educandos mais subsídios para seu empoderamento e emancipação é essencial. Isso passa inevitavelmente pelo acesso à cultura escrita, que se dá mediante o acesso a uma educação linguística de qualidade. É preciso, portanto, sistematizar uma pedagogia do letramento para a EJA capaz de contribuir de forma mais efetiva na formação de educandos, com maior capacidade de agência cívica.

Nesse sentido, julga-se importante ressaltar o papel fortalecedor dos projetos de letramento, por se considerar que estes podem oferecer relevantes contribuições à implementação de uma nova pedagogia do letramento na EJA. Podendo, assim, imprimir maior eficácia às políticas públicas voltadas para o público a que se destina essa modalidade de ensino, conforme propõem Santos e Oliveira (2012). 
Defende-se, por fim, que o trabalho com os gêneros discursivos em projetos de letramento pode contribuir para tornar a escola um espaço mais comprometido com uma educação linguística de qualidade, capaz de ensinar o educando "a usar bem a nossa língua”, como diz o poeta na epígrafe deste trabalho. Tornando-se uma arena de luta e resistência à opressão das classes sociais marginalizadas, a escola pode conduzir alunos e professores a pensar, coletiva e solidariamente, soluções para seus problemas, pondo em relevo uma proposta de educação emancipatória, desenvolvida a partir do trabalho com práticas de letramento cívico, voltadas para as necessidades de agência cívica daqueles que se vinculam a esse tipo de projeto.

\section{REFERÊNCIAS}

ADORNO, T. W. Educação e emancipação. São Paulo: Paz e Terra, 1995.

BAKHTIN, M. Questão de literatura e de estética: a teoria do romance. São Paulo: Hucitec, 1990. Estética da criação verbal. São Paulo: Martins Fontes, 2003.

BAKHTIN, M.; VOLOCHINOV, V. N. Marxismo e filosofia da linguagem. São Paulo: Hucitec, 2000.

BARTON, D.; HAMILTON, M.; IVANIC, R. (Orgs.). Situated literacies. London: Routledge, 2000. p. 01-06.

BAYNHAM, Mike. Literacy practices: investigating literacy in social contexts. London: Longman, 1995.

BAZERMAN, C. Gênero, agência e escrita. São Paulo: Cortez, 2006. . Escrita, gênero e interação social. São Paulo: Cortez, 2007.

BORDIEU, P. A economia das trocas simbólicas. São Paulo: Perspectiva, 1987.

BRASIL, Secretaria de Educação Fundamental. Parâmetros Curriculares Nacionais: Língua Portuguesa. Brasília: MEC/SEC, 1998.

CHOULIARAKI, L.; FAIRCLOUGH, N. Discourse inlate modernity: rethinking critical Discourse Analysis. Edinburg: Edinburg University, 1999.

FAIRCLOUGH, N. Discurso e mudança social. Brasília: UNB, 2001.

FREIRE, P. Educação como prática da liberdade. Rio de Janeiro: Paz e Terra, 1971. . Educação e mudança. Rio de Janeiro: Paz e Terra, 1979. . Pedagogia da autonomia: saberes necessários à prática educativa. São Paulo: Paz e Terra, 1996. Conscientização: teoria e prática da libertação. São Paulo: Cortez e Moraes, 2001.

FREIRE, P.; MACEDO, D. Alfabetização: leitura da palavra leitura do mundo. Rio de Janeiro: Paz e Terra, 1990.

GIROUX, H. A. Pedagogia radical: subsídios. São Paulo: Cortez: Autores associados, 1983. Os professores como intelectuais. PortoAlegre: Artes Médicas, 1997.

HANKS, W. F. Língua como prática social: das relações entre língua, cultura e sociedade a partir de Bourdieu e Bakhtin. São Paulo: Cortez, 2008.

IVANIC, R. The discourses of writing and learning to write. Language and education. v. 18, n. 3, p. 220-245, 2004.

KLEIMAN, A. B. (Org.). Os significados do letramento: uma perspectivasobre a práticasocial da escrita. Campinas, SP: Mercado de Letras, 1995.

. O processo de aculturação pela escrita: ensino de forma ou aprendizagem da função? In:

KLEIMAN, A. B.; SIGNORINI, I. O ensino e a formação do professor: alfabetização de jovens e adultos. Porto Alegre: Artes Médicas do Sul, 2000.

Processos identitários na formação profissional - o professor como agente de letramento. In: CORRÊA, M. L. G.; BOCH, F. (Orgs.). Ensino de língua: representação e letramento. Campinas, SP: Mercado de Letras, 2006. 
. EJA e o ensino da língua materna: relevância dos projetos de letramento. EJA em Debate,

Florianópolis: IFSC, v. 1, n. 1, p. 23-38, nov. 2012. Disponível em:

$<$ http://incubadora.periodicos.ifsc.edu.br/index.php/EJA/article/view/318/pdf\#.UMZxB6xGOb>.

LAZERE, D. Reading and Writing for Civic Literacy: the critical citizen's guide to argumentative rhetoric. U.S.A: Paradigm Publishers, 2005.

MCLAREN, P.A vida nas escolas: uma introdução à Pedagogiacríticanosfundamentos da educação. Porto Alegre: Artes Médicas, 1997.

Multiculturalismo revolucionário: pedagogia do dissenso para o novo milênio. Porto Alegre: Artes médicas Sul, 2000.

MILLER, C. R. Estudos sobre: gênero textual, agência e tecnologia. Recife: Ed. Universitária da UFPE, 2009.

PÉREZ, F. C.; GARCÍA, J. R. A alfabetização como meio de recriar a cultura. In: Ensinar ou aprender a ler e a escrever? Porto Alegre: Artmed, 2001.

OLIVEIRA, M. S. Projetos: uma prática de letramento no cotidiano do professor de língua materna. In: OLIVEIRA, M. S.; KLEIMAN, A. Letramentos múltiplos: agentes, práticas e representações. Natal: EDUFRN, 2008.

; TINOCO, G. M. A. M.; SANTOS, I. B. A. Projetos de letramento eformação de professores de língua materna. Natal: EDUFRN, 2011.

SANTOS, I. B. A. Do que o texto é para o que significa: outroolharsobreproduçõestextuaisescritas de alunos do ensinomédio. Natal, 2004. Dissertação (Mestrado em Linguística Aplicada) - Universidade Federal do Rio Grande do Norte.

Projetos de letramento na educação de jovens e adultos: o ensino da escrita em uma perspectiva emancipatória. Natal, 2012. Tese (Doutorado em Estudos da Linguagem/Linguística Aplicada) Universidade Federal do Rio Grande do Norte - UFRN.

SANTOS, I. B. A.; OLIVEIRA, M. S. Políticas públicas na educação de jovens e adultos: projetos de letramento, participação e mudança social. EJA em Debate, Florianópolis: IFSC, v. 1, n. 1, p. 39 a 56, nov. 2012. Disponível em:

$<$ http://incubadora.periodicos.ifsc.edu.br/index.php/EJA/article/view/318/pdf\#.UMZxB6xGOb>.

WENGER, E. Communities of practice: learning, meaning and identity. Cambridge: Cambridge university Press, 1998.

Recebido em 19/10/12. Aprovado em 15/01/13. 